\title{
REALITY OF GENDER RELATIONS: THE ROLE AND POSITION OF WORKERS IN THE MARITIME AND FISHERIES SECTOR
}

\author{
Widya Hasian Situmeang, Hanifah Firda Fauzia Gunadi, Inditrya Wisnu
}

Rural Sociology, IPB University. Kampus IPB Dramaga, Bogor, West Java. Email: Widya_hasi12t@apps.ipb.ac.id, hanifah_gunadi3795@apps.ipb.ac.id, inditrya_wisnu@apps.ipb.ac.id

\begin{abstract}
Gender relations between women and men should be in an equal situation. Unfortunately, the construction of Indonesian society, especially at the village level is still gender bias. Women tend to be in an unfavorable position, not even seen in development. this paper intends to raise the role and position of workers based on gender relations, especially in coastal and fisheries communities. The lack of gender studies in coastal communities as well as lack of attention and efforts to encourage gender equality in coastal and fisheries communities has led to higher gaps in gender relations. This paper mainly looks at how issues of gender injustice, sexual violence and inequality in accessing new technologies, especially digital technology in coastal communities. This paper is enriched with literature studies and the results of previous research and compared with legal products and agreements on gender equality.
\end{abstract}

Keywords: gender, coastal, community

\section{INTRODUCTION}

Women and men as subjects of development should have equal opportunities and space in development. The initiation of various policies that encourage gender equality at both national and global levels, in fact shows the opposite. Women are still the subject of development that is lagging behind, and not even seen in development in various places. One of the legitimacy of this fact is the re-entry of aspects of gender equality in the $5^{\text {th }}$ Sustainable Development Goal (SDG's) point, after previously also being one of the points in the Millennium Development Goals (MDG's). Even at MDG's, $3^{\text {rd }}$ point, women's empowerment is clearly stated to be one of the targets.

The policy struggle for women in development at the global level also has a long history. Some products of international agreements are made to fight for equality of space for women in development internationally and are expected to encourage the birth of various derivative policies at the national level. Some products of the agreement include the 1984 Convention on the all forms of Discrimination Against Woman (CEDAW), 1995 Beijing Form for Action (BPFA), 2000 Millennium Development Goals (MDGs), and 2015 Sustainable Development Goal (SDG's). 
At the national level, Indonesia also has various historical struggles to encourage the birth of policies that try to strengthen and guarantee the position of women in development. Since independence, various policy frameworks such as Increasing the Role of Women in the Old Order, Empowering Women in the New Order, post-reform Gender Mainstreaming and Gender Equity (GFC) were encouraged by the central government to become the basis for the preparation of various public policies. But in reality, until now there are still a few legal and policy products that really contain statements that protect women's rights as citizens, especially in fulfilling their daily needs. The various levels of government policies that are still dominated by gender blind practices make the steps to realize gender equality in development still a difficult task in this country. This gap has a major impact on women living in rural and remote areas.

Coastal communities have certain characteristics in the social structure of their communities that are influenced by livelihoods and specific geographical conditions. Coastal communities cannot be separated from various gender issues in development. The division of labor between men and women, for example, is something that always happens in order to meet family needs, including for coastal communities. Various other gender issues also require attention in order to realize equal development for men and women in coastal areas.
There are various studies on gender issues in coastal communities. The results of various studies try to see how the position of women and men in development in communities that depend on the fisheries and marine sector. One of them is the research conducted by Karnaen (2013) conducting research on communities in Tanjung Pasir Village, Teluknaga District, Tangerang Regency with the aim of looking at the role of gender and decision making in community households that depend on fulfilling their daily needs in the fisheries sector. Not only that, the People's Coalition for Fisheries Justice (KIARA) issued a Policy Paper which voiced unrest over the absence of space in the DPR-RI version of the Bill on the Protection and Empowerment of Fishermen, Fish Cultivators and Salt Farmers dated 27 August 2015, which put fishermen women as part of the community with political recognition of their constitutional rights.

One form of legal product that tries to reaffirm the urgency of gender equality in development policies in the fisheries sector is the Minister of Fisheries Minister Regulation (Permen KP) Number 28 of 2016 concerning Implementation Guidelines for Program Monitoring and Evaluation / Gender Responsive Activities of the Ministry of Maritime Affairs and Fisheries (KKP); KP Candy Number 51 of 2016 concerning Guidelines for Mapping Gender Mainstreaming in the Field of Marine and Fisheries in the Region; and Decree of the Minister of Marine Affairs No. 67 of 2016 concerning the Roadmap for 
Mapping Gender Mainstreaming in the MPA. Through this legal product, it is expected that various fisheries policies will at least begin to provide a clear space for equality of women and men in development in the fisheries sector. However, in practice, there are still many gender issues and most of them are closely related to the differentiation of reproductive, productive and social roles between women and men. Following are some explanations on the issue of gender injustice in development in the marine and fisheries sector, sexual harassment, and opportunities for male and female adaptation to technology in the fisheries and marine sector.

\section{THE METHOD}

This paper was prepared using the method of reviewing literatures that has relevance to the topics covered by gender relations and the role of women workers in development, especially in the fisheries and marine sector. Then, the literatures review result are synthesized to produce a new paper.

\section{DISCUSSION AND REVIEW}

\section{GENDER INJUSTICE ISSUES IN DEVELOPMENT OF MARINE AND FISHERIES SECTOR}

\section{Discrimination of male and female workers}

In essence, God created men and women with differences inherent in each of them. This difference will not be a problem

1 The view of Women's Solidarity on the draft bill on the Protection and Empowerment of Fishermen, Fish Cultivators and Salt Farmers. Source: http:// www.solidaritasperempuan.org/sub/wp-content/ and does not need to be disputed if there are no parties or conditions that differentiate men and women. This distinction is commonly referred to as discrimination. Discrimination in gender relations can occur for both men and women. However, in general, women who are always more discriminatory are due to the assumption that women are in the second class under men. Discrimination can be in the form of differences in wages, working hours, position and status of male and female workers in the fisheries and marine sector.

In the journey in fighting for gender equality in the fisheries and marine sector, a form of discrimination against female fishermen can be found when the government issued a draft law (Bill) concerning the Protection and Empowerment of Fishermen, Fish Cultivators and Salt Farmers which was later passed into Law (UU ) Number 7 of 2016. Responding to the draft, the nationallevel Women's Solidarity Organization gave several views, one of which was the absence of explicit recognition of fishing women, women fish farmers or salt farmers. Women are only recognized as part of fishing households, fish farmers and salt farmers. This shows that the role of women is not recognized as a fisherman so that it will have implications for not counting women in the development planning process so that women cannot get access, control, the opportunity to participate and benefit from development programs and empowerment. This will strengthen discrimination against female fishermen. ${ }^{1}$

uploads / 2013 / 04 / Pandangan-SolidaritasPerempuan-terhadap-RUU-Nelayan-Pembudi-DayaIkan-dan-Petambak-Garam.pdf 
Not recognizing women directly as fishermen will also be an obstacle in resolving the legal process. Like the experience of Solidaritas Perempuan when conducting a Citizenship Claim (Gugatan Warga Negara) on the privatization of water management in Jakarta where the identity of fishermen women as witnesses in the trial was questioned by the Chief Judge because of the general perception of the community that fishermen were only male. ${ }^{2}$

The lack of recognition of women as fishermen has resulted in the difficulty of women's access to information on business technology, training, assistance and business assistance because before the massive movement that fought for justice for women fishermen, empowerment programs such as the 2007 Coastal Community Economic Empowerment and the National Community Empowerment Program (PNPM) in 2010 only for fishermen with a special definition of 'male fishermen'. The fishing village community in Teluk Village, Banten, adheres to the value that the obligation of women is to take care of the household and help her husband find additional family economies so that they are not prioritized in productive activities (Istiana, 2014). This shows that there was discrimination between fishermen and male fishermen which caused women to be second (subordinated) by assuming that women who worked productively were a form of assistance to their husbands.
In terms of income and outpouring of working time in productive activities such as research conducted by Karnaen and Amanah (2013), male fishermen always have greater income and outpouring of productive work time than female fishermen (wives). In fisherman households, wives play the role of 'helpers' of husbands in earning a living, especially when husbands have low incomes so the wives of fishermen look for other income such as searching for shells, selling gado - gado or other foods. While his work, such as preparing equipment for husbands to catch fish, is not counted into the wife's productive activities.

Karnaen and Amanah (2013) also show that the outpouring of men's time in earning a living which consists of fishermen, fisheries products and fish farmers is always greater than women. This shows that men have greater access to productive activities in the public sphere. Whereas, the outpouring of time for women in business activities and participating in training outside of their main livelihood is always greater than that of men.

To overcome the problem of discrimination and subordination of female fishermen, the empowerment program must also be given to female fishermen to increase competence and access to information and productive activities so that women also have equal positions with men in economic development. That way, women fishermen will have access and opportunities that are equal to men and can enjoy the same results. 
Sexual Harassment and Violence in the Public Sphere / community

Harassment and violence against gender differences in Indonesia have recently occurred frequently and are quite alarming especially for women who are very vulnerable to violence and abuse. The government has institutions that build data based on reports on gender based violence, including in the realm of marriage, personal and community relations or workers. This actually enables the handling of acts of abuse and violence that occurs against women tends to occur mainly in sexual harassment. Various Data from the National Commission on Protection of Women and Children shown in this writing are also limited in relation to the role and position of workers based on the reality of gender relations. The discussion will bring up data on the results of the acquisition of government institutions regarding cases of violence and sexual harassment of women in the public / community domain in Indonesia.

Violence experienced by women especially occurs because there are several economic and social trigger factors. The forms of violence include physical violence, sexual violence and discrimination against gender differences where gender equality is not obtained and considers men to have more power while women are powerless. On the National Records Committee (CATAHU) Fact Sheet of 2018, there were many findings, including cases of violence against women, there were around 348,446 handled during
2017, consisting of 335,062 cases handled by the Religious Courts (BPA) originating from case data / case, then handled by a network of service institutions for women victims of violence, namely Pengadalayaan around 13, 384 cases by 237 largest partner institutions in 34 provinces. National Commission on Violence Against Women sent 751 forms to rescue institutions throughout Indonesia with a return response rate of $32 \%$ with 237 forms.

The National Women's Commission in CATAHU always records violence against women in 3 domains, namely, including personal / private domains; community public domain; and the realm of the country. In the realm of a surprising finding in CATAHU 2018 , most of the data compiled is data from BPA cases / cases which from 2007-2017 showed an increase in numbers compared to 2017 of 348.44 cases which increased by $25 \%$ compared to the previous year 2016 namely 259,150 from the results of the data from National Women's Commission cannot conclude that cases of violence are increasing but more to the number of victims who have dared to report. There is also a percentage of the forms of violence that occur from the public / community domain which include $13 \%$ physical violence, $76 \%$ sexual violence with 911 cases of sexual abuse; sexual abuse 704 cases; rape of 699 cases; and intercourse 343 cases, $6 \%$ psychological violence with threats of 69 cases; and other psychological cases of 129 cases, and trafficking of $5 \%$ with 
191 cases with 3 additional cases of migrant workers.

The most form of violence against women is sexual, then physical violence becomes the second most. Sexual violence as the highest number in the community domain was most widely reported to police agencies, UPPA, NGOs, and P2TP2A. ${ }^{3}$ The National Women's Commission through data on service institutions, finds the form and type of violence against women in the public / community domain.

The public / community domain is usually in the work environment, community, neighboring, or educational or school institutions. In this area the details of complaints received by the Women's National Commission in CATAHU 2018 throughout 2017. The most cases are violence in the workplace, 50 cases, then rape 45 cases, and sexual abuse as many as 37 cases. From these cases illustrating data in work situations is very vulnerable to violence and sexual abuse. Not significantly about the data desired in this scientific writing, but in summary, the trend that appears in this area is women workers who are more often subjected to violence and sexual abuse.

In the female fishermen sector, what usually happens is more in the form of psychological violence or threats to jobs as female fishermen who are considered not included in fishing work but only become fish

3 Is the result of data from the National Commission for Women's Protection with the presentation of data cleaning workers and fish sellers in markets that are not valued as fishermen workers. women. In the definition explained by Law No. 7 of 2016 concerning the protection and empowerment of fishermen, the intended law is very positive in protecting small fishermen. However, this definition of fishermen makes women not accounted for in the fisheries sector.

The cases obtained were fishermen in the Asmat tribe who dominated women as captured fishermen. The daily life of women in Asmat is indeed a fisherman by going out to sea to find fish with tools that are still very traditional by using rowboats to go fishing because women there who are called as mama are not able to drive fishing boats. From morning to evening going to sea is their job to find fish for their own consumption and also to be marketed. However, violence and sexual harassment can occur if women are weak when they are going out to sea alone without being accompanied by their husbands, which is a crime when working. But on the other hand this scientific writing has not found any harassment of female fishermen from various references obtained. There was a journal that gave another presentation about cases of sexual harassment that had never happened in the thousand islands related to women fishermen. But this, makes things very surprising. Is the job as a fisherman safer than other jobs that are prone to violence and sexual abuse.

generated through data collection of institutional cases through partners in 34 provinces in $2017 / 2018$ 
Adaptation of Men and Women to new technology

Technology in the fisheries and marine sector can be distinguished by technology in cultivation, technology in capture fisheries, postharvest processing, and information and communication technology (ICT). According to the Ministry of Communication and Information (2015) Information and communication technology (ICT) refers to the use of electronic equipment (especially computers) to process certain activities. ICTs have a potential contribution to play a role in achieving significant economic, social and environmental benefits. Some of the problems found in using this technology are managerial problems, infrastructure, human resources and culture. There is a very high disparity between the availability of information objects and the ability of the subject to utilize this technology.

There is a bias in the use and empowerment of ICT programs between the agricultural sectors in the broadest sense. Large programs are still dominated by food crops and horticulture as well as livestock. Some pilot programs for cyber extensions are in increasing public access to information in Indonesia, including: (1) CTLC - Microsoft Unlimited Potential (UP) Program is a Microsoft global initiative that has been implemented worldwide since 2003. The main goal of the Unlimited Potential program is to reduce digital divide for people who have limitations, (2) Partnerships for e-Prosperity for the Poor
(Pe-PP - Pilot Project to Reduce Poverty by Utilizing Information and Communication Technology). The form of activity is the construction of telecentres and mentoring for a year to build a culture of information and communication in rural communities, (3) Poor Farmers' Income Improvement through Innovation Projects (PFI3P) or Farmer Income Improvement Programs through Innovation (P4MI) is a Ministry of Agriculture program with funds from ADB loans carried out by the IAARD to improve the welfare / income of farmers on marginal land through agricultural innovations from the production stage to marketing results.

The target of at least the three major programs is still focused on food crop farmers, horticulture and livestock. Communities that depend on the fisheries and marine sectors clearly get far fewer opportunities than communities with terrestrial ecosystems. This inequality is certainly a description of the position of women in the opportunity to access communication technology in communities in the fisheries and marine sector. If there is an opportunity to access technology, surely men are first exposed to women. This is as stated by Loader (1998) which states that women are the first group to be eliminated from the workforce due to digitalization.

KIARA (2015) states that women have a large share in fisheries and marine activities. The outpouring of women's working time even reaches 17 hours per day, with a range 
of at least 48 percent of fishermen's family income coming from the contribution of women fishermen. However, women are still the number two subject of development in terms of adaptation to technology. In the capture fisheries sector, fishing activities that are more loaded with the use of technology such as fishing gear and ICT equipment are dominated by men. It is very rare to find female fishermen who go out to sea, except for small boats with a period of daily screens and not too far from the coastline.

Nurlaili and Muhartono (2017) in their research in the Bay of Jakarta identified several activities of women who were mostly fishermen's wives, namely: in the capture fisheries sector consisting of fish traders, the private sector, laborers, households and others; in aquaculture consists of farmers, traders and households; fish processing consists of fish processors, and households. In addition, as family workers, women also help husbands (fishermen) repair fishing gear, make new fishing gear, prepare supplies to market catches. The magnitude of the role of fishermen's wives in economic activities is motivated by the dependence of fishing communities who rely solely on one source of livelihood so women must help to provide for family income (Kusnadi, 2003).

Asirin and Argo's study (2017) states that the use of ICT by fishermen in Indramayu is in the scope of knowing capture fisheries rules and policies, to know the issue of climate change and its adaptation strategies, and to know the development of fishing techniques and equipment. However, this study does not specify who has access to the use of these technologies based on sex. Some of the communication and information technologies used by fishermen in Indramayu are basically information equipment such as mobile phones, SSB radios, community radio, running text, GPS, Fish finder, download posters from the internet and TV. According to the Ministry of Communication and Information, based on the results of a 2015 survey, fishermen in North Sumatra who use vessels with a capacity of less than 5 GT are almost certainly not using a lot of ICT except HP in supporting their business. Whereas for fishermen who are above 15 GT usually use a lot of GPS and Fish finder and satellite or radio communications. GPS is used as a guide, while the fish finder is used to determine the position of the fish. Whereas satellite telephones and radio communications are tools for communication with other parties.

\section{CONCLUSION}

Development should provide equal opportunities for men and women as subjects of development, both in planning and enjoying the results of the development. The history of struggle at the international and national levels shows that women are still subject to subordination in development. The struggle for equality between women and men is also felt in the fisheries and marine 
sectors. The regulations have been produced that underlie Gender Mainstreaming. But, in practice there are still many issues of gender injustice that occur in the households in the fisheries and marine sector.

To overcome the problem of discrimination and subordination of female fishermen, the empowerment program must also be given to female fishermen to increase competence and access to information and productive activities so that women also have equal positions with men in economic development. That way, women fishermen will get access and opportunities that are equal to men and can enjoy the same results.

\section{Reference List}

Asirin, Argo TA. 2017. Penggunaan Teknologi Informasi dan Komunikasi dan Aplikasinya terhadap Ketangguhan Mata Pencaharian Nelayan. Journal of Regional and Rural Development Planning. Vol. 1 (1): 1-15

Ikhsan, Fuady dan Titien, Yusnita. 2016. Persepsi Masyarakat Pesisir Terhadap Kepemimpinan Perempuan Nelayan Di Pulau Pramuka Kepulauan Seribu. Indonesian Journal of Agricultural Economics (IJAE). Vol. 7, Nomor 1, Juli $2016: 1-12$

Istiana. 2014. Akses perempuan nelayan dalam kegiatan produktif : studi kasus di Desa Teluk, Kecamatan Labuan, Kabupaten Pandeglang, Banten. Buletin Riset Sosek Kelautan dan Perikanan. Vol 9. No.1. Mei 2014.
[JurnalPerempuan] Melihat Perempuan asmat bekerja. Dapat diakses di: https:// www.jurnalperempuan.org/wacanafeminis/archives/04-2019

Karnaen SMN, Amanah S. 2013. Peranan Gender dalam Rumah Tangga Perikanan di Desa Tanjung Pasir, Kecamatan Teluknaga, Kabupaten Tangerang. Sodality: Jurnal Sosiologi Pedesaan Vol 01, No.02. Agustus 2013

[KIARA] Koalisi Rakyat untuk Keadilan Perikanan. 2015. Kertas Kebijakan Perempuan Nelayan Berhak Mendapatkan Perlindungan dan Pemberdayaan dari Negara

[KOMINFO] Pusat Penelitian dan Pengembangan Penyelenggaraan Pos dan Informatika Badan Penelitan dan Pengembangan Sumber Daya Manusia Kementerian Komunikasi dan Informatika. 2015. Pemanfaatan dan Pemberdayaan Teknologi Informasi dan Komunikasi pada Petani dan Nelayan (Survey Rumah Tangga dan Best Practices)

[Komnasperempuan] Komisi Nasional Anti Kekerasan Terhadap Perempuan merupakan lembaga independen negara untuk penegakan hak asasi manusia dan perempuan Indonesia. Catatan Tahunan CATAHU 2018. Dapat diunduh di : https://www. komnasperempuan.go.id/publikasicatatan-tahunan?page $=2$ 
Kusnadi. 2003. Akar Kemiskinan Nelayan. Yogyakarta: LKIS.

Loader BD. 1998. Cyberspace Divide: Equality, agency, and policy in the information society. London: Routledge.

Nurlaili, Muhartono R. 2017. Peran Perempuan Nelayan dalam Usaha Perikanan Tangkap dan Peningkatan Ekonomi Rumah Tangga Pesisir Teluk Jakarta. Jurnal Sosek KP Vol 12 No 2 Desember 2017: 203-212
[RI] Pemerintah Republik Indonesia. 2016. Undang - Undang Republik Indonesia Nomor 7 Tahun 2016 tentang Perlindungan dan Pemberdayaan Nelayan, Pembudidaya Ikan dan Petambak Garam. Jakarta (ID). Dapat diunduh di : http://kkp.go.id/ an-component/media/upload-gambarpendukung/kkp/UUD\%20Nomor\%20 7\%202016.pdf 